\title{
Croatian Teacher Competencies Related to the Creation and Implementation of Education Policy
}

Vesna KovaČ ${ }^{\star 1}$, Branko RafajaC ${ }^{2}$ ANd Iva BuCHBERGER ${ }^{3}$

$\approx$ This research was conducted in order to gain a preliminary insight into the general orientation and range of opinions of 396 primary and secondary school teachers in Croatia toward the a) importance of their competencies related to the education policies; b) cognition and mastering of the competencies related to the education policies; c) the actual activity of primary and secondary school teachers in the creation and implementation of education policies. Research data were collected on the basis of a survey methodology, using an online questionnaire in the form of a Likert scale. In addition, the questionnaire contained two open questions. The analysis of results has clearly shown that primary and secondary school teachers in this research evaluated their competencies related to the education policies to be an important part of the competency profile of teachers. Teachers have made relatively high evaluations of their cognition and mastery of the competencies related to the education policy processes within school. In contrast, somewhat lower evaluations have been given to the mastery of competencies associated with the knowledge of education system, i.e. activity outside the school context. The evaluations of scale items related to the preconditions and personal activity in decision making and the implementation of education policy within the school vary in the range of average values or slightly above that.

Keywords: education policy, school management, teachers' competencies, teaching profession, educational reforms, teachers' decision making

$1 \quad{ }^{\star}$ Corresponding Author. University of Rijeka, Faculty of Humanities and Social Sciences in Rijeka, Department of Education, Croatia; vkovac@ffri.hr

2 University of Rijeka, Faculty of Humanities and Social Sciences in Rijeka, Department of Education, Croatia

3 University of Rijeka, Faculty of Humanities and Social Sciences in Rijeka, Department of Education, Croatia 


\section{Kompetence hrvaških učiteljev v povezavi z oblikovanjem in implementacijo izobraževalnih politik}

Vesna KovaČ*, Branko RAFajaC In Iva Buchberger

$\propto$ Raziskava je bila izvedena za pridobitev preliminarnih informacij o splošni orientiranosti in različnih mnenjih 396 osnovnošolskih in srednješolskih učiteljev na Hrvaškem o: a) pomembnosti njihovih kompetenc, povezanih z izobraževalnimi politikami; b) poznavanju in obvladanju kompetenc, povezanih z izobraževalnimi politikami; c) dejanskih aktivnostih osnovnošolskih in srednješolskih učiteljev pri oblikovanju in implementaciji izobraževalnih politik. Podatki so bili zbrani s pomočjo ankete; uporabljen je bil spletni vprašalnik v obliki Likertove lestvice. Poleg tega je vprašalnik obsegal še dve odprti vprašanji. Analiza rezultatov je jasno pokazala, da osnovnošolski in srednješolski učitelji, ki so sodelovali v raziskavi, ocenjujejo svoje kompetence, povezane $\mathrm{z}$ izobraževalnimi politikami, kot pomemben del kompetenc učiteljev. Učitelji so sorazmerno visoko ocenili svoje poznavanje in obvladanje kompetenc, povezanih s procesi izobraževalnih politik znotraj šole. Nasprotno pa so nekoliko nižje ocenili obvladanje kompetenc, povezanih s poznavanjem izobraževalnega sistema, kot na primer aktivnosti zunaj šolskega konteksta. Ocene postavk lestvic, povezanih s predpogoji in z osebnimi aktivnostmi pri odločanju in implementaciji izobraževalnih politik znotraj šole, se gibajo okrog povprečnih vrednosti ali nekoliko nad njimi.

Ključne besede: izobraževalne politike, vodenje v šoli, učiteljeve kompetence, poklic učitelja, izobraževalne reforme, odločanje učiteljev 


\section{Introduction}

In most international reports that specify the factors of successful education systems and schools (such as, OECD, 2010, 2013; Sahlberg, 2012), among the most commonly specified factors are a high degree of participation of teachers (along with school principals and their associates) in making decisions on important aspects of school (and the education system) performance, and the appreciation of teaching profession in society. Apart from the declarative level, the content of major policy documents that guide the development of the education system at the international and national levels provides very little knowledge about the actual efforts of the authorized decision makers in education policies aimed at strengthening the professional capacities and the role of teachers as active participants in the creation of education policy. ${ }^{4}$

Describing the effect of global field in education policy, Rizvi and Lingard (2010) argue that global education policy is established, created, disseminated and implemented in a different manner in comparison to when individual nation states had central authority over it. Nowadays, the main guidelines for the creation of global education policy stem from policy documents and activities of international and transnational organizations such as the OECD, the World Bank, UNESCO and the EU. Furthermore, new actors have taken part in the creation of education policies, thus developing new (often interconnected) vertical and horizontal forms of education management (Connolly \& James, 2011). In addition, value-driven orientations, which are specifically refracted in the relation between the advocacy of economic efficiency of education and the maintenance of social equality and justice through education are undergoing changes as well (Ben-Peretz, 2009). One of the consequences of these actions is the creation of a certain distance between the place and the actors through whom (global) policies are formed and the place and the actors through whom those policies will be implemented (locally). State authorities, as mediators in these processes, often show a stronger tendency to meet the global trends, while teachers, who are direct implementers of policy decisions in their schools and classrooms, are rarely consulted on the issues relevant to the implementation. The result of this type of relationship can be seen in the frequent dissatisfaction of teachers with policy decisions, difficulties during implementation and,

4 At the time of the completion of this research, working paper "Strategy for Education, Science and Technology" (Government of the Republic of Croatia, 2013) has been published and sent to a public hearing. The introduction points out that "Croatia recognizes education and science, as well as their development, as priorities that can bring long-term stability, economic prosperity and security of cultural identity" (p. 7), while the autonomy of institutions and professionals in the field of education and science is recognized as the basic principle on which this strategy is based. 
ultimately, in unsuccessful reforms. This paper is based on the assumption that the success of the education system and educational reforms depends largely on the professional capacities and willingness of teachers to implement new decisions in their everyday school practice (Fullan, 2007, 2010). Therefore, this paper will pay attention to the role of teachers in the adoption and implementation of key decisions at the school level.

\section{Trends in global education policies: strengthening of teachers' competencies}

Experts agree that the ultimate goal of global education policies is to enable citizens to effectively take part in and benefit from the global world economy (OECD, 2010). A more thorough review and comment on significant (global) education policy initiatives and documents, especially teacher education, is available in more recent publications (e.g. European Commission, 2010; Valenčič-Zuljan \& Vogrinc, 2011). The review starts with the emphasis on the final decades of the 2oth century as the beginning of changes and new challenges in (teacher) education. The professional education of teachers is listed as one of the indicators for monitoring the implementation of the Lisbon objectives in the field of education (European Council, 2009). Nowadays, this particular form of education is one of the indicators for monitoring the implementation of the objectives of the Europe 2020 Strategy, in which one of the emphasized priorities is investment in human resources and education. This type of an investment is seen as a contribution to the economic development of a country.

Recently, international research and debates about teachers' competencies have been extremely dynamic. Therefore, their lists of teachers' competencies are constantly updated in line with the changes and challenges that teachers face in the context of the effects of global education policies. The most influential comparative study of (teachers') competencies was driven and carried out under the TUNING Educational Structures project in Europe (Gonzales \& Wagenaar, 2008). Recent studies dealing with competencies have also been conducted in Croatia. For example, research has been conducted on quality of teacher education and other aspects of the teaching profession from the perspective of primary school teachers (Pavin, Rijavec, \& Miljević-Riđički, 2005). The first part of the questionnaire, conducted for the purpose of that research, contained the elements regarding major areas of teacher's work. Teachers had to evaluate the list of competencies with regard to the degree of acquisition during their initial education and with regard to the degree of satisfaction with the content, organization and execution of the initial education. In connection 
to that, it is important to mention studies on (teacher's) competencies that, in addition to the finding on the situation in Croatia, also provide a comparative aspect of the Croatian position in relation to other countries in the region (e.g. Spasovski, 2010).

The current study has resulted in the creation of a comprehensive list of teachers' competencies grouped into several fundamental areas of professional performance. Moreover, it resulted in an interpretation of teachers' evaluations on the importance of mastering certain (groups of) competencies. There is a list of 39 teacher's competencies divided into four groups of competencies: a) competencies related to values and upbringing of the child, b) competencies related to the understanding of education system and contributions to its development, c) competencies related to knowledge of the subject area, pedagogy and curriculum and d) competencies related to self-evaluation and professional development. The research results indicate that in the (initial) teacher education programs the least represented elements are those that develop competencies related to the social role of teachers, understanding the education system and education policy or raising awareness of the importance of their contribution to the development of education. This information is significant, since it is in compliance with development perspectives and the role of teaching profession in the context of successfully coping with the challenges of the global education policies (such as, Rizvi \& Lingard, 2010; OECD, 2010; Ben-Perez, 2009). These are the following competencies (Spasovski, 2010): willingness (of teachers) to participate in public debates on education topics; monitoring and participating in the activities of relevant bodies at various levels of education system; the ability to participate in projects in the field of education; understanding national priorities in education; willingness to cooperate with the local community in organizing program activities (e.g. organising practical training in local businesses); ability to anticipate new labour market requirements related to education; ability to conduct research for the advancement of education; understanding of legislation and authority in education; willingness to cooperate with the stakeholders of health and social institutions; and willingness to participate in school development plans.

Competencies that belong to this group can also be found in other lists used in recent studies: the ability to identify potential links between aspects of education theory and education policy and practice, understanding the structure and purpose of education systems, the ability to understand the process of development and change in the community, the ability to understand trends in education and recognition of their implications (Drudy, Gunnerson, \& Gilpin, 2009). According to three studies that support the development of 
school policies (Piesanen \& Välijärvi, 2010), the teachers' competencies that were found to be particularly important were those dealing with cooperation, collaboration and leadership.

Moreover, the list of the so-called secondary professional roles of primary and secondary school teachers that were discussed in the TALIS research must be mentioned. Through those roles, teachers must respond to the expectations of the wider community. The list of roles consists of the ability to communicate effectively with a range of stakeholders within and outside the school on issues related to education; knowledge of education policy and organization of the education system, the ability to participate in public debates on education policy from the perspective of the implementation education policy in schools and cooperation in managing schools (Scheerens, 2010). Debates on the expected professional competencies of teachers are closely connected with the organization of their initial and permanent professional development, as well as other settings of their professional identity. However, current debates and research do not provide data on the extent to which national education policies empower the desired professional capacity of teachers.

\section{Position and Role of Teachers in the Adoption and Im- plementation of the Key Decision in Education Policies}

Two groups of research bring significant information on different aspects of the position and role of teachers in adoption and implementation of decisions: those who deal with policy implementation at the education system level and those who observe different aspects of school management (Kovač et al., 2014).

Most research on policy implementation emphasizes its two main dimensions. The first is the success of the implementation, i.e. the extent to which the policy has been implemented into practice to suits its purpose. The second is the efficiency of implementation, i.e. the extent to which the implementation of policy has achieved the desired improvements in practice (McLaughlin, 1987; Fitz et al., 1994; Honig, 2006; Fuhrman et al., 2007; Cooper et al., 2008). The success and the efficiency of policy implementation depends on the mutual interaction of various factors, the most prominent of which are those related to the characteristics of individual policy decisions and those related to the environments in which specific policy decisions should be implemented (Honig, 2006).

Assuming that in the study of education policy teachers are commonly seen through their role in the implementation of important policy decisions, it is important to draw attention to the increasing advocacy of the expansion of their role and competence profile. The course and characteristics of policy 
implementation will largely depend on the roles that teachers occupied in the earlier stages of the policy process. Most education policy researchers indicate that the knowledge of the nature of relationships that existed between the various participants in the stage of making policy decision is crucial for understanding the policy implementation process (e.g. McLaughlin, 1987; Honig, 2006). At the same time, it is important to overcome the distance between the "top" and the "down" (Fuhrman et al., 2007). The importance of overcoming this distance is confirmed by the results of the recent PISA study (OECD, 2010, 2013), which associates successful education systems with a higher level of autonomy of schools and teachers in making key decisions. ${ }^{5}$ However, this finding should be viewed in the context of other factors that characterize the individual education systems: strengthening the autonomy of teachers will not have a positive effect if the process is not followed by ensuring/strengthening the professional capacity of teachers for qualitative decision making.

During the implementation of an education policy, one must always rely on the ability and possibility of teachers and other professionals to interpret and reinterpret the policy in a way that suits their knowledge, beliefs and values attributed to specific policies (McLauglin, 1987; Fitz et al., 1994). In other words, teachers, as professionals, rarely execute instructions "from above" without prior consideration of the appropriateness, significance and the possibility of adapting policy decisions to the real practice in which the implementation is expected to take place. Therefore, in the situations of "top-down" decision making, it is very likely that the implementation will not fully correspond to the intentions of a decision maker. However, these phenomena cannot be considered to be desirable or undesirable without prior analysis, since they usually reflect positive motives, i.e. focused on finding the best practices for the benefit of end-users. The incorrect implementation sometimes happens due to the lack of necessary competencies and other capacities or because of personal frustration caused by the loss of certain resources after the implementation of new policies (Palmer \& Snodgrass Rangel, 2011).

Desurmont et al. (2008) considered the different roles and types of teachers' participation in educational reforms. The researchers started with the reforms that were more often initiated by the national government. In those type of reforms, the modes of teachers' involvement were created from the "top

5 The results of the PISA study (OECD, 2013) show that the connection between school autonomy and students' achievement can be seen in the allocation of autonomy. In particular, in the creation of curriculum, in assessment process and in making decisions on the allocation of resources. Regarding this issue, Croatia, among the countries who participated in the PISA study, has one of the lowest degree of autonomy (the value of the achieved index of autonomy is -o.8). It is important to mention that Croatia has a complete absence of autonomy in the issues regarding the election of school principals, i.e. in defining their authorities and responsibilities. 
down" perspective. Accordingly, the researchers noticed the most frequent modes of involvement: a) low level of involvement, when only a few selected experts / representatives of teachers participate in the preparation of the reform documents; b) participation through representatives of trade unions (which may or may not be regulated by law as an obligatory way of involvement); and c) large numbers of consulting teachers. The last item can be realized through participation in pilot projects, precisely structured public discussions or through participation in larger studies in which the teacher serves as a direct source of relevant information.

The current tendency of strengthening the involvement of teachers in the reform process is explained via the intention of achieving two basic goals: gathering information from those who have the best knowledge of the actual school conditions (which may facilitate the implementation of the reform) and reducing resistance in the implementation of reforms. Even though Croatia did not participate in this research, it can be assumed that Croatia does not apply those modes of teachers' involvement that ensure their strong participation in reforms. ${ }^{6}$

Recent research results of various aspects of school management and education systems (e.g. Jackson \& Marriott, 2012; Jarvis, 2012; Somech, 2010; Hallinger \& Heck, 2010; Hulpia et al., 2011) indicate that school management is a process that enables the crucial connection of school classrooms, individual schools and the education system as a whole, integrating internal processes to improve schools with externally induced reforms. Through its series of comparative studies and publications dedicated to school management, the OECD specifically advocates the strengthening of the so-called distributive management forms of school and school systems (Pont et al., 2008). Those forms are considered to be the more distinct guidelines for the development of education policy at the global level. The distribution of management roles and responsibilities to teachers and other professionals within and outside the school (special attention ought to be paid to school boards) has appeared due to the increased scope of roles and responsibilities of school principals. It is assumed that schools have become overly complex organizations that operate in an increasingly complex environment. Therefore, it is very difficult for a single

6 In the pilot-research, the results of which are presented in this paper, teachers were asked to describe their perception of the most important trends in the Croatian education policy. Among others, they described basic programs and projects at the national level in which they take part, the adoption of which made significant changes in ther daily work. The most cited projects are: standardization of the national curriculum in elementary schools (Croatian National Educational Standard) and other interventions relalated to the inovation of curriculum (introducing new content such as education on health and citizenship), implementation of State Graduation Exam in secondary schools, the strenghtening of lifelong education policy and the application of self-evaluation of schools. 
person or a small group of employees responsible for the school management to make appropriate decisions. Involving teachers in the decision-making process is positively associated with the increased efficiency of schools, labour productivity and professional capacity of teachers, student achievement, as well as with the formation of desirable characteristics of a school's climate and environment (Bruggencate et al., 2012; Robinson et al., 2008; Choi Ho Wa., 2010). Advocacy of the distributive type of school management is based on four assumptions: decisions in which teachers take part will be more qualitative, teachers' motivation to implement them will be stronger, realization of their professional capacity will be better, and their job satisfaction will be higher.

Somech (2010) emphasizes that the appropriate involvement of teachers in the decision-making process must satisfy four basic assumptions: the inclusion must be defined by the official policy of the school management, their participation must be direct, the influence on decision making must be powerful, and the issues to be decided upon must be perceived as important. It should be noted that true characteristics of the distributive school management include the equal access of all participants to the necessary resources and equal right to vote in the decision-making process. Jackson and Marriot (2012) observed and compared the efficiency of schools in respect to their organizational features. Moreover, they evaluated different combinations of the level of influence that school principals and teachers have on making key decisions. They concluded that the most successful schools are those in which school principals and teachers make high evaluations of their level of influence on the decisionmaking process. The abovementioned research determined that a mere $27.22 \%$ of schools appertain to the most desirable category. Similar tendencies can be observed in the studies that compare the degree of influence of teachers in making key decisions in relation to the influence of other stakeholders inside and outside the school. The more successful schools are those in which teachers and other stakeholders make high evaluations of their influence on the decisionmaking process. Moreover, those schools are characterized by the presence of (desirable) characteristics of the distributive type of management.?

If only the legal and formal assumptions for the functioning of distributive management in Croatian schools were to be analysed, it could be relatively quickly concluded that the practice of distributive management is strongly represented and well established in these aspects. There is a wide range of stakeholders who have an ensured participation in decision-making on various

7 Within the PISA study, school principals answered the question regarding the frequency of taking certain activities, such as involvement of teachers in those processes. The value of index of managing school with the involvement of teachers for Croatian schools is only o.1. 
aspects of school performance. ${ }^{8}$ Moreover, the function of the Teacher Council enables all teachers and professional associates to participate in decisionmaking on a range of school activities. In contrast, the structure of the School Board provides regular participation of representatives of parents and founders in the decision-making process. However, an insight into the role, structure and scope of work of these bodies provides only information on their purpose, on the composition of the members who strive to achieve this purpose, and on the inventory of their activities.

In the context of Croatian education policy, there is lack of sufficient empirical data on teachers' qualification for participation in the creation and implementation of key decision in education policy. Moreover, there is little data on the realization of the necessary assumptions for giving teachers a more active role in the school management. Therefore, empirical research has been conducted in order to obtain insight into the realization of those assumptions.

\section{Purpose, Objective and Research Method}

This research was conducted in order to gain preliminary insight into the general orientation and range of opinions of teachers employed in primary and secondary schools on the issues of teachers' competencies related to the education policy. Apart from an insight into the issue and into a general orientation and range of opinions, an additional purpose of this research is to create a theoretical and empirical basis for the operationalization of a more extensive research project in this issue. In particular, this purpose is related to the research of specific roles of various stakeholder and interferences in their interaction that can cause dysfunction in the system.

Therefore, the research questions are as follows:

1. What are the perceptions of primary and secondary school teachers in Croatia towards the importance of teachers' competencies related to the creation and implementation of education policies?

2. How do Croatian teachers evaluate their actual cognition and mastering of competencies related to the education policy?

8 Duties and responsibilities of the educational institutions in pre-tertiary education in Croatia are divided among bodies (authorities) of dual orientation of expertise. For some of the bodies, the main purpose is to take care of the resources necessary for the operation (material, human, financial, etc.), and they are usually appointed as the governing bodies, e.g. School Board in elementary and secondary schools. Others are oriented towards the successful realization of pedagogical processes and are called professional bodies of educational institutions, e.g. primary and secondary Teacher Councils, developmental pedagogical services and the principal who connects and coordinates the work of both (Elementary and Secondary Education Act, Official Gazette No. 87/2008). 
3. How do Croatian teachers evaluate their actual participation in the creation and implantation of key decisions at the school level?

Regarding the above-stated questions, the collection of the quantitative data was based on the evaluation of the provided statements according to the level of agreement. Additionally, teachers were given two open questions. In the first, they were asked to state positive features of Croatian education policy and in the second they were asked to state negative features of the same policy. Thematic categories of data were selected based on the collected and analysed responses (Milas, 2005). The selected categories provide deeper understanding and facilitate the interpretation of data on the motivations, roles and actual activities of teachers in making key decisions in education policy. The recognition of teachers as important factors of education policy constitutes an important group of desirable features of education policy. As for the negative features, several selected categories support the results of this research: comments focused on the poor status of teachers and the teaching profession, the inadequacy of decisions in relation to pedagogical profession, and distrust in the work of educational authorities.

The research is intended to be a preliminary determination of the orientation and range of opinions towards the importance of mastering the competencies in education policy and participation in the implementation of policy decisions. Consequently, simple random samples were not extracted from the population group. Instead, a modified random sample group of participants were extracted from population group in throughout Croatia. The procedure consisted of a random selection of seven counties from the list of all Croatian administrative territorial units (21 counties). The research included 396 primary and secondary school teachers from all the schools in the selected counties. The questionnaire was distributed via county or city offices for education.

Data were collected via an online questionnaire in the form of Likert scale in which informants had to evaluate the given statements according to the level of agreement to a specific statement: " 1 " meaning strongly disagree and " 5 " strongly agree. Anonymity was guaranteed to all participants and the average time to fill in the questionnaire was 15 minutes. The questionnaire was available to participants for a period of two weeks. In a cover letter, the questionnaire was explained in detail, starting from the purpose of research, basic concepts to the key role of the research participants. Data analysis was performed using the SPSS statistical program. Descriptive statistics (shown as the mean, standard deviation and percentages) was used in the analysis of the collected data. A T-test for independent samples was used in order to determine the difference 
in evaluations of certain statements with regard to the separate independent variables (discussed below).

The list of the evaluated teachers' competencies related to education policy is content-wise and logically validated and in compliance with recent pieces of research presented in the theoretical part of the paper (Pavin, Rijavec, \& Miljević-Riđički, 2005; Drudy, Gunerson, \& Gilipin, 2009; Spasovski, 2010; Scheerens, 2010). Moreover, the list is aligned with policy recommendations that define new primary/secondary school teachers' competencies.

The importance and mastery of the derived competencies was evaluated through ten statements (scale items). Incentives and the actual participation of teachers in designing and implementing policies were evaluated through eight statements. It is important to state that this research did not include an evaluation of the role of teachers in the decision-making process with respect to different types of decisions, e.g. at the school level or at the education system level (such as in OECD, 2010; Jackson \& Marriott, 2012). Instead, the research opted for finding the general evaluation of the role of teachers in decision-making processes.

Apart from opinions, the questionnaire collected the following features of participants: gender, qualifications, work experience, type of school in which they are employed, subject area and status with regard to the realized professional progression. However, the analysis of these variables generally showed no statistically significant differences in the examined opinions.

\section{Analysis and Interpretation of Results}

\section{Teachers' evaluation on importance of competencies related to education policy}

The presented results (Table 1 ) clearly show that teachers evaluated all the competencies related to policies as an important part of their competency profile (average evaluations are around and above 4). Even though this type of data seems expected and uninteresting, its actual significance emerges when placed into the context of the current curriculum for the Teacher Education Program at Croatian universities. In fact, content related to these competencies is rarely or not at all present in the initial education and in the lifelong learning program for Croatian teachers. However, one must not ignore the fact that all groups of competencies, within the range of completely irrelevant to very important, were evaluated as important or very important. The result may indicate that teachers expect a certain level of their involvement in dealing with activities that go beyond their primary professional role (teaching students). 
Table 1. Teachers' evaluations on the importance of competencies related to education policy

\begin{tabular}{lcc}
\hline \multirow{2}{*}{ Statements } & \multicolumn{2}{c}{$\begin{array}{c}\text { Importance of } \\
\text { competencies }\end{array}$} \\
\cline { 2 - 3 } & $\mathrm{M}$ & $\mathrm{SD}$ \\
\hline $\begin{array}{l}\text { Ability to adapt the educational process to the requirements of the } \\
\text { labour market }\end{array}$ & 4.44 & 0.778 \\
\hline $\begin{array}{l}\text { Knowledge of legislation related to education (law, regulations, decisi- } \\
\text { ons, strategies, etc.) }\end{array}$ & 4.32 & 0.799 \\
\hline $\begin{array}{l}\text { Understanding of the effects of the global trends on activities in tea- } \\
\text { ching and school practice }\end{array}$ & 4.28 & 0.764 \\
\hline $\begin{array}{l}\text { Knowledge of global trends in education } \\
\text { Qualification for active participation in the preparation of development } \\
\text { plans for school }\end{array}$ & 4.27 & 0.785 \\
\hline $\begin{array}{l}\text { Qualification for active participation in projects and research related to } \\
\text { the development of education }\end{array}$ & 4.23 & 0.873 \\
\hline $\begin{array}{l}\text { Ability to take initiative in making decisions related to school perfor- } \\
\text { mance }\end{array}$ & 4.20 & 0.818 \\
\hline $\begin{array}{l}\text { Capacity to actively participate in public debates on education topics } \\
\text { Qualification for active participation in activities of relevant governing } \\
\text { bodies at the school level (school boards, etc.) }\end{array}$ & 4.09 & 0.906 \\
\hline $\begin{array}{l}\text { Knowledge of the education system structure at the national level } \\
\text { (structure, education level, number and composition of decision-ma- } \\
\text { king bodies related to education and education system, etc.) }\end{array}$ & 3.93 & 0.882 \\
\hline
\end{tabular}

\section{Teachers' self-evaluation on cognition and mastering of the} competencies related to education policies

The results of evaluations of the cognition and mastering of each competence (Table 2) indicate that teachers provide relatively high evaluations of their cognition and mastering of all the competencies, especially those related to their activities within the educational institution. Most of those statements were evaluated with an average value greater than 4 . Competencies related to the knowledge of education system, i.e. actions outside the framework of the educational institution, were evaluated slightly lower. 
Table 2. Teachers' self-evaluation on cognition and mastering of teachers' competencies related to the cognition of education policy

\begin{tabular}{|c|c|c|}
\hline \multirow[t]{2}{*}{ Statements } & \multicolumn{2}{|c|}{$\begin{array}{l}\text { Cognition and } \\
\text { mastering of the } \\
\text { competencies }\end{array}$} \\
\hline & M & SD \\
\hline $\begin{array}{l}\text { I am able to participate in the relevant governing body at the school } \\
\text { level (school boards, etc.) }\end{array}$ & 4.31 & 0.871 \\
\hline $\begin{array}{l}\text { I am able to participate in the projects and research related to the } \\
\text { development of education }\end{array}$ & 4.25 & 0.785 \\
\hline $\begin{array}{l}\text { I am able to adapt the educational process to the requirements of } \\
\text { labour market (content, mode) }\end{array}$ & 4.24 & 0.799 \\
\hline $\begin{array}{l}\text { I am able to participate in the preparation of development plans for } \\
\text { school }\end{array}$ & 4.24 & 0.854 \\
\hline $\begin{array}{l}\text { I am able to take the initiative in making decisions related to school } \\
\text { performance }\end{array}$ & 4.19 & 0.903 \\
\hline I have knowledge of global trends in education & 4.02 & 0.756 \\
\hline $\begin{array}{l}\text { I have knowledge of the education system structure at the national } \\
\text { level (structure, education level, number and composition of the decisi- } \\
\text { on-making bodies related to education and the education system, etc.) }\end{array}$ & 3.99 & 0.895 \\
\hline I am able to participate in public debates on education topics & 3.97 & 0.863 \\
\hline $\begin{array}{l}\text { I understand the effects of global trends on activities in teaching and } \\
\text { school practice }\end{array}$ & 3.9 & 0.862 \\
\hline $\begin{array}{l}\text { I know the legislation related to education (laws, regulations, decisions, } \\
\text { strategies, etc.) }\end{array}$ & 3.88 & 0.85 \\
\hline
\end{tabular}

The results of t-test for independent samples showed a significant difference between the evaluations of primary school employees and secondary school employees. The difference is seen in two statements: Understanding the effects of global trends on activities in teaching and school practice $(\mathrm{t}(376)=$ $-2.267, \mathrm{p}<0.05)$ and The ability to take the initiative in making decisions about school performance $(\mathrm{t}(371)=-1.1997, \mathrm{p}<0.05)$. In both cases, secondary school employees provide higher evaluations, which may lead to the assumption that secondary school employees participate more frequently in decision-making processes.

However, teachers' evaluations of the importance and mastery of the competencies related to the understanding and implementation of education policy should be interpreted with certain restrictions. In fact, self-evaluations related to mastery of competencies should not be viewed as indicators of the actual mastering of these competencies. Instead, they should be viewed as a potential capacity of teachers to participate in decision-making processes at the school level. 


\section{Evaluations of assumptions and activity of teachers in creation and} implementation of decisions in domain of education policy

It should be noted that statements provided in the questionnaire are fully compliant with trends that are being advocated through relevant policy documents in the field of education, as well as through the reports on (factors of) efficiency of education systems. Therefore, the values that rarely exceed the average of teachers' evaluations do not reflect a favourable situation that can ensure the success and sustainability of educational reforms (Table 3 ). The evaluations of statements related to the awareness and personal activity in making policy decisions and implementing them at the school level vary in the range of average values or slightly above that.

Table 3. Evaluations of assumptions and activity of teachers in creation and implementation of education policies at the school level

\begin{tabular}{lcc}
\hline $\begin{array}{l}\text { Statements related to the assumptions and activity in creation and } \\
\text { implementation of education policies at the school level }\end{array}$ & M & SD \\
\hline I am regularly involved in professional training programs. & 4.58 & 0.747 \\
\hline I am regularly informed on important issues of school performance. & 3.54 & 1.203 \\
\hline The principal encourages me to make changes at the school level. & 3.39 & 1.277 \\
\hline School environment is supportive of my work. & 3.38 & 1.202 \\
\hline My opinion is appreciated in making key decisions at the school level. & 3.19 & 1.201 \\
\hline I actively participate in the implementation of educational reforms. & 3.05 & 1.192 \\
\hline $\begin{array}{l}\text { Information needed for the successful implementation of educational } \\
\text { reforms are available to us. }\end{array}$ & 2.91 & 1.167 \\
\hline The school where I work is well equipped. & 2.86 & 1.241 \\
\hline
\end{tabular}

The results of t-test showed a significant difference between the evaluations of teachers who have made professional progression and those who have not. The difference is seen in two statements: Regular involvement in professional training programs $(\mathrm{t}(326)=3.203, \mathrm{p}<0.01)$ and Availability of required information for the successful implementation of educational reforms ( $\mathrm{t}$ (324) $=2.991, \mathrm{p}<0.01)$. In both cases, teachers who made professional progression make higher evaluations of the provided statements. Bearing in mind the activities that Croatian teachers have to undertake in order to gain the right to professional progression (Elementary and Secondary Education Act, 2008), it is possible to assume that the more appropriate system of rewarding teachers could significantly contribute to the enhancement of desirable trends of involving teachers in these processes. 
The relatively low evaluations of their active participation in the implementation of educational reforms $(\mathrm{M}=3.05)$ leads to the assumption that national educational authorities failed to implement modes of the high level of involvement of teachers (Desurmont et al., 2008). However, this information may indicate that the implementation of those modes did not result in desired effects. In this context, particular attention should be paid to the responses that teachers provided to open questions. Those responses confirm that their messages and opinions do not reach the education authorities, even in situations in which there is a formal opportunity to engage in a public debate on making draft decisions. The consequences of this situation can be seen in adoption of decisions that are not appropriate for the teaching environment. In fact, teachers frequently report such situations:

- " $\quad$ "There are no public debates before the introduction of changes."

- $\quad$ "Every reform is implemented haphazardly, teachers are not even asked for an opinion, and when they are randomly asked, their opinion is not appreciated."

- "Creators of education policies are often not familiar with the actual conditions in schools and the possibility of realizing the set objectives."

- $\quad$ "People who create education policies do not work in schools, most of them never worked in schools."

In addition, the following comments illustrate low evaluations of active participation in the implementation of reforms:

- "Experts are not contacted in terms of reforms. Always jumping in decision-making, without the prior analysis. No experimental programs. Everyone comes, dragging their own people along with them, and makes changes."

- $\quad$ "Education policy is not created by teachers who are competent to implement it into practice."

Low evaluations of material conditions $(\mathrm{M}=2.86)$ are also closely related to low evaluations of participation in the implementation of decisions, as evidenced by the following statement:

- $\quad$ "Frequent reforms, badly thought though, haphazard, and teachers have to adjust and find a way to realize it; a lot of schools do not have the conditions for implementation, so then, how will the students acquire the necessary competencies? First, everything should be well prepared, financially secure, and then go into the realization; then, the success (motivation / realization) would be much better." 
Judging by the teachers' statements, low evaluations of their participation in the implementation of education reforms is likely associated with a poor status of teachers and teaching profession in society. Moreover, it is associated with the lack of confidence in the performance and competence of the representatives of education authorities. Commenting on the unfavourable status of teachers and teaching profession, teachers most often singled out poor treatment by the education authorities and other entities that are associated with school performance.

- "Teaching staff is not paid enough and therefore is unmotivated."

- "Downgrading teachers and their rights in the process of teaching."

- "The dignity of teachers has been degraded. Successful teachers do not receive any 'bonus' or award, other than a pat on the shoulder. You can't live on that."

A low score of evaluations of the availability of information needed for the successful implementation of reforms $(M=2.91)$ is another indicator of underutilized potential for strengthening the involvement of teachers in the creation and successful implementation of reforms.

- "Participants of education have lack of information."

- "Reforms and changes are chaotic, under-planned and they are imposed to teachers without explanation."

In this case, teacher training possibilities should be noted. In fact, the Agency for Education provides possibilities that are partially related to the professional preparation of teachers for the implementation of the ongoing projects and programs. However, teachers point to some limitations in this segment:

- "Lack of resources for professional training and systematic guidance of teachers in the implementation."

- "Due to a lack of finances, a small number of teachers participate in professional training and projects."

Since being informed is a necessary condition for teachers' successful and active involvement, it is imperative to find and implement mechanisms that will encourage teachers to use the available information. Moreover, those mechanisms may serve as a powerful factor in raising awareness of the importance of their role in creating and implementing educational reforms.

Finally, as expected, evaluations related to the activity of teachers in decision-making processes at the school level have higher values. This can partially be clarified by the legally acquired right to make decisions through 
collective participation in school management bodies. However, low evaluations of statements related to the appreciation of teachers' opinions in decisionmaking process $(\mathrm{M}=3.19)$ and principal's encouragement to make changes at the school level $(M=3.39)$ should be noted. It seems that the acquired right to make decision often relies on participation in bodies that are mainly advisory and are not involved in making a large number of decisions relevant for the school performance.

\section{Discussion and conclusions}

The analysis of results clearly showed that the participants in this research evaluated teachers' competencies related to the education policies as an important part of competency profile of primary and secondary school teachers. Teachers have made relatively high evaluations of their cognition and mastering of the competencies, especially those related to activities within school. In contrast, somewhat lower evaluations have been given to the mastering of competencies associated with the knowledge of education system, i.e. activities outside the school context. Three important messages can be derived from this part of research. First, attention should be given to the designers of teachers' education programmes, emphasizing the necessity for inclusion the development of this particular set of competences as a part of initial teacher education, with reference to Fullan's (2007) assumption about the necessity of linking all levels of management of the education system in order to ensure successful and sustainable educational reform.

The second message of this research should be referred to decision-makers at the highest (national) level of authority. The message is the following: primary/secondary school teachers in Croatian schools should be strongly involved in the process of creating education policy, with better appreciation of their professional competencies and capacities. Research results confirm that their messages and opinions do not reach the education authorities, even in situations in which there is a formal opportunity to engage in a public debate on making draft decisions.

The third message should be directed to the school principals: the process of stronger involvement should start with the creation of better conditions for strengthening their role in decision-making processes at the school level. Research indicates a serious lack of information needed for the successful implementation of educational reforms in spite of various teacher training possibilities, which are partially related to the professional preparation of teachers for the implementation of the ongoing projects and programs. Empowered and 
involved teachers can ensure the adoption of more appropriate decisions, aimed at improving school and teaching achievements.

The results can also be interpreted in the context of debates about the appropriateness of certain decisions in an actual school situation. A number of the reviewed teachers' statements have reported insufficient material conditions of schools, or on adoption of decisions that are not appropriate for certain school environment. The findings of the similar research studies point to decision makers who do not take sufficient account of the variety of local conditions in which certain decisions or innovations will have to take place (Honig, 2006). Undesirable consequences of such practice usually lead to teachers' negative perceptions towards educational authorities, distrust in quality and appropriateness of decisions made by politicians, opinion that key decisions are made by individuals who are not familiar with the teaching practice. The results of this research are not significantly different from the results of similar studies in other national systems. Experts from the Centre for Education Policy in Belgrade (Pantić \& Čekić -Marković, 2012) report similar results based on the analysis of data collected via interviews with focus groups of teachers in Serbia. However, differences in the relationship between "politicians" and "practitioners" are a quite common phenomenon in the context of education policy (Kovač, 2007). Therefore, the obtained results should be seriously considered. Moreover, desired approaches to solving or mitigating the identified problems should be defined.

Finally, it is important to bear in mind that research results give optimistic assumptions for a more active involvement of teachers in process of decision making: positive results of self-evaluations of teachers in terms of their professional capacity, agreement in evaluation of the importance of competencies for participation in the creation and implementation of education policies, and a mostly positive attitude towards the necessity of involvement of teachers in the process of decision making. According to the announcements of national and international authorities in the field of education policy, educational reforms will surely continue to be implemented in full intensity. Greater success and sustainability of those reforms will be ensured through the improvement of communication links between all levels of the education system management and through the improvement of competencies of all relevant stakeholders in this process. Therefore, the continued research of this issue is one of the important strategic objectives. Topics that were opened in this research indicate to the necessity of research extension and particularly to the necessity of collecting data from several other groups of stakeholders. In doing so, Fullan's assumption (2007) on the importance of the vertical and horizontal interconnection within the education system would be entirely fulfilled. 
Note:

“The research of teachers' competencies and roles in the creation and implementation of education policies" is a part of a scientific research project "University and the external environment in the context of the European integration processes" (009-0oooooo-0931). This project was, in the period from 2007 to 2013, supported by the Ministry of Science, Education and Sports of the Republic of Croatia. The survey was conducted in September 2012. This work has been supported in part by the University of Rijeka under the project "Investigating school leadership in Croatian schools" (13.04.1.3.13).

\section{References}

Ben-Peretz, M. (2009). Policy-Making in Education. A holistic approach in response to global changes. Lanham: Rowman \& Littlefield Education.

Bruggencate, G., Luyten, H., Scheerens, J., \& Sleegers, P. (2012). Modeling the Influence of School Leaders on Student Achievement: How Can School Leaders make a Difference? Education Administration Quarterly, 48(4), 699-732.

Choi Wa Ho, D. (2010). Teacher Participation in Curriculum and Pedagogical Decisions: Insights into Curriculum Leadership. Educational Management Administration\&Leadership. Retrieved 23.9.2012 from http://ema.sagepub.com/content/38/5/613

Connolly, M., \& James, C. (2011). Reflections on Developments in School Governance: International Perspectives on School Governing Under Pressure. Educational Management and Leadership, 39(4), 501-509.

Cooper, B. S., Cibulka, J. G., \& Fusarelli, L. D. (2008). Handbook of Education Politics and Policy. New York: Routhledge.

Desurmont, A., Forsthuber, B., \& Oberheidt, S. (2008). Levels of Autonomy and Responsibilities of Teachers in Europe. Brussels: Eurydice.

Drudy, S., Gunnerson, L., \& Gilpin, A. (Eds.) (2009). Reference Points for the Design and Delivery of Degree Programmes in Education. Bilbao: Universidad de Deusto.

EC/EACEA/Eurydice. (2013). Key Data on Teachers and School Leaders in Europe. Luxemourg: Publications Office of the EU.

Elementary and Secondary Education Act (2008). Official Gazette, 87/ 2008.

European Council. (2009). Council Conclusions of 12 May 2009 on a Strategic Framework for European Cooperation in Education and Training. Official Journal of the European Union. Retrieved 24.9.2012 from http://eurlex.europa.eu/LexUriServ/LexUriServ.do?uri=OJ:C:2009:119:0002:0010:EN:PDF European Commission. (2010). Europe 2020 - A strategy for smart, sustainable and inclusive growth. Retrieved 23.9.2012 from http://www.mobilnost.hr/prilozi/o5_1300804774_Europa_2020.pdf Fitz, J., Halpin, D., \& Power, S. (1994). Implementation Research and Education Policy: practice and prospects. British Journal of Educational Studies, 42(1), 53-69. 
Fuhrman, S. H., Cohen, D. K., \& Mosher, F. (2007). The State of Education Policy Research. Theoretical Concepts and Research Methods. Mahwah, New Yersey: Lawrence Erlbaum Associates, Publishers. Fullan, M. (2010). All Systems Go: The Change Imperative for Whole System Reform. Thousand Oaks, California: Corwin.

Fullan, M. (2007). The New Meaning of Educational Change. New York: Teachers College, Columbia University.

Gonzales, J., \& Wagenaar, R. (Eds.) (2008). Tuning Educational Structures in Europe. Universities' contribution to the Bologna Process. Bilbao: Universidad de Deusto.

Government of the Republic of Croatia. (2013). Strategy for Education, Science and Technology: working material. Zagreb: Government of the Republic of Croatia. Retrieved 25.9.2013 from http:// www.vlada.hr/hr/preuzimanja/strategije/strategija_obrazovanja_znanosti_i_tehnologije_radni_ materijal_rujan_2013/strategija_obrazovanja_znanost_i_tehnologije_radni_materijal/(view_online)/1 Hallinger, P., \& Heck, R. H. (2010). Leadership for Learning: Does Collaborative Leadership Make a Difference in School Improvement? Educational Management, Administration and Leadership, 38(6), 654-678.

Honig, M. I. (2006). New Directions in Education Policy Implementation. Confronting Complexity. Albany, NY: State University of New York Press.

Hulpia, H., Devos, G., \& Van Keer, H. (2011). The Relation Between School Leadership from a Distributed Perspective and Teachers' Organizational Commitment: Examining the Source of the Leadership Function. Education Administration Quarterly, 47(5), 728-771.

Jackson, K. M., \& Marriot, C. (2012). The Interaction of Principal and Teacher Instructional Influence as a Measure of Leadership as an Organisational Quality. Educational Management \& Leadership, $48(2), 230-258$.

Jarvis, A. (2012). The Necessity for Collegiality: Power, Authority and Influence in the Middle. Education Administration and Leadership, 4o(4), 480-493.

Kovač, V., Rafajac, B., Buchberger, I., \& Močibob, M. (2014). Education Policy from the Perspective of Teachers in Croatia. Napredak. In press.

Kovač, V. (2007). Approaches to education policy analysis. In V. Previšić, N. N. Šoljan, \& N. Hrvatić (Eds.), Pedagogy - towards lifelong education and knowledge-based society (pp. 515-521). Zagreb: Croatian Pedagogical Society.

McLaughlin, M. W. (1987). Learning from Experience: Lessons from Policy Implementation.

Educational Evaluation and Policy Analysis, 9(2), 171-178.

Milas, G. (2005). Research methods in psychology and other social sciences. Zagreb: Naklada Slap. OECD. (2010). PISA 2009 Results: What Makes a School Successful? - Resources, Policies and Practices (Volume IV). Retrieved 12.10.2012 from http://dx.doi.org/10.1787/9789264091559-en OECD. (2013). PISA 2012 Results: What Makes Schools Successful? Resources, Policies and Practices (Volume IV). PISA, OECD Publishing.

Palmer, D., \& Snodgrass Rangel, V. (2011). High Stakes Accountability and Policy Implementation: Teacher Decision Making in Bilingual Classrooms in Texas. Educational Policy, 25(4), 614-647. 
Pantić, N., \& Čekić-Marković, J. (Eds.) (2012). Teachers in Serbia: attitudes towards profession and education reforms. Belgrade: Center for Education Policies.

Pavin, T., Rijavec, M., \& Miljević-Riđički, R. (2005). Perception of the quality of teacher education and some aspects of teaching profession from the perspective of primary school teachers. In V.

Vizek - Vidović (Ed.), Lifelong education of teachers: multiple perspectives. Zagreb: Institute for Social Research in Zagreb.

Piesanen, E., \& Välijärvi, J. (2010). Education and Training 2010: Three studies to support School Policy Development - final report. Finnish Institute for Educational Research. Retrieved 23.10.2012 from http://ktl.jyu.fi/img/portal/17545/TEC_FINAL_REPORT_12th_Apr2010_WEB.pdf?cs=1271922032

Pont, B., Nusche, D., \& Moorman, H. (2008). Improving School Leadership. Volume 1: Policy and Practice. Paris: OECD.

Rizvi, F., \& Lingard, B. (2010). Globalizing Educational Policy. London: Routledge.

Robinson, V. M. J., Lloyd, C. A., \& Rowe, K. J. (2008). The Impact of Leadership on Student

Outcomes: An Analysis of the Differential Effects of Leadership Types. Educational Administration

Quarterly, 44(5), 635-674.

Sahlberg, P. (2012). Lekcije iz Finske. Zagreb: Školska knjiga.

Scheerens, J. (Ed.) (2010). Teachers' Professional Development: Europe in international comparison.

Luxembourg: Office for Official Publications of the European Union.

Somech, A. (2010). Participative Decision Making in Schools: A Mediating-Moderating Analytical Framework for Understanding School and Teacher Outcomes. Education Administration Quarterly, 46(2), 174-209.

Spasovski, O. (2010). Teacher Competence as a Basis for Teacher Education: Tuning Teacher Education Curricula in Five Western Balkan Countries. In B. Hudson, P. Zgaga, \& B. Åstrand (Eds.), Advancing Quality Cultures for Teacher Education in Europe: Tensions and Opportunities (pp. 87-104). Umeå: Umeå School of Education, Umeå University.

Valenčič - Zuljan, M., \& Vogrinc, J. (Eds.) (2011). European Dimension of Teacher Education: Similarities and Differences. Ljubljana, Kranj: Faculty of Education, University of Ljubljana, The National School of Leadership in Education. 


\section{Biographical note}

VESNA Kovač, dr., is associate professor at the University of Rijeka Faculty of Humanities and Social Sciences, Department of Education. Her research interest has been firstly focused on the education policy, management and leadership in higher education, while the recent research focus has been also focused on the education policy, management and leadership within the pre-tertiary education. She is currently appointed as the head of Doctoral Study Programme of Education and as the head of the Center of Teacher Education.

BRANKo RAFAJAC, dr., is full professor at the University of Rijeka - Faculty of Humanities and Social Sciences, Department of Education and former dean of the faculty. His main research interest has been focused on the sociology of education, education policy and management, methodology of educational research, methodology of cultural research and statistics. He is currently a principal investigator of a research project Investigating School Leadership From a Distributed Perspective in Croatian Schools supported by the University of Rijeka. He was a winner of the National Award „Ivan Filipovićc for his contribution in higher education in 2006.

IVA BUCHBERGER is junior researcher at the University of Rijeka - Faculty of Humanities and Social Sciences, Department of Education. Her recent research focus is concerned with the field of the education policy, management and leadership within the pre-tertiary education. Her interest is also concerned with the critical thinking, reading and writing, didactics and philosophy of education. She is currently doctoral student at Doctoral Programme in Education at the University of Rijeka - Faculty of Humanities and Social Sciences, Department of Education. 